\title{
BENZODIAZEPINE RECEPTOR LIGAND ACTIONS ON GABA RESPONSES. $\beta$-CARBOLINES, PURINES
}

\author{
JOHN H. SKERRITT and ROBERT L. MACDONALD * \\ Department of Neurology, University of Michigan, Ann Arbor, MI 48109, U.S.A.
}

Received 30 September 1983, revised MS received 17 January 1984, accepted 28 February 1984

J.H. SKERRITT and R.L. MACDONALD, Benzodiazepine receptor ligand actions on GABA responses: II. $\beta$-Carbolines, purines, European J. Pharmacol. 101 (1984) 135-141.

The effects of several $\beta$-carboline and purine ligands for benzodiazepine receptors were studied upon GABA (4-aminobutyric acid) responses and upon diazepam enhancement of GABA responses, using mouse spinal cord neurons in dissociated cell culture. While the potent convulsant $\beta$-carboline DMCM (methyl-6,7-dimethyoxy-4-ethylcarboline-3-carboxylate), reduced GABA responses, methyl-carboline-3-carboxylate $(\beta \mathrm{CCMe})$ and the corresponding ethyl ester $(\beta C C E t)$ did not alter GABA responses. The propyl ester $(\beta C C P r)$ enhanced GABA responses in a concentration-dependent fashion, while both $\beta C C M e$ and $\beta C C P r$ blocked diazepam enhancement of GABA responses. $\beta C C P r$ may thus have partial agonist activity. Two purines with moderate benzodiazepine receptor affinity, 1-methylisoguanosine (MeIG) and 6-dimethylaminopurine (DMAP), weakly enhanced GABA responses. MeIG also significantly antagonized diazepam enhancement of GABA responses. Inosine and hypoxanthine had no apparent actions upon GABA responses or upon diazepam enhancement of such responses. The results with $\beta$-carbolines are consistent with their behavioural profile in vivo and with neurochemical studies of their effects upon GABA-benzodiazepine receptor complexes. Furthermore, certain purines are also able to interact with these complexes.

\section{Benzodiazepine-GABA receptor complex Spinal cord neuronal cultures $\quad \beta$-Carboline-3-carboxylates} Amino acid electrophysiology Purines

\section{Introduction}

The identification of specific binding sites in the central nervous system for benzodiazepines (Braestrup and Squires, 1977; Möhler and Okada, 1977) has prompted searches for endogenous ligands for these sites. In addition to various peptides (Chiu and Rosenberg, 1981; Guidotti et al., 1983), $\beta$-carboline-3-carboxylate ethyl ester ( $\beta$ CCEt) (Braestrup et al., 1980) and certain purines including inosine and hypoxanthine (Skolnick et al., 1978; Asano and Spector, 1979; Möhler et al., 1979) have been suggested to serve such a role. While some $\beta$-carbolines and purines

* To whom all correspondence should be addressed: Neuroscience Laboratory Building, 1103 East Huron, Ann Arbor, MI 48109, U.S.A. also have benzodiazepine agonist or antagonist-like activity, thorough evidence that similar endogenous compounds modulate benzodiazepine receptors in vivo is lacking. $\beta$ CCEt has been shown more recently to be an extraction artifact and unlikely to occur in the central nervous system (Braestrup and Nielsen, 1980; Möhler, 1981).

However, the alkyl esters of $\beta$-carboline-3carboxylic acid are in general potent ligands for benzodiazepine binding sites and as a class have a range of pharmacological profiles. While the compounds act as benzodiazepine antagonists, some are anxiogenic and potent convulsants (e.g. methyl-6,7-dimethoxy-4-ethyl- $\beta$-carboline-3-carboxylate, DMCM), others proconvulsant (e.g. $\beta C C E t)$ and compounds with larger alkyl substitutions such as $\beta$-carboline-3-carboxylate propylester $(\beta C C P r)$ have anticonvulsant activity (Cepeda 
et al., 1981; Braestrup et al., 1982; Oakley and Jones, 1982; Valin et al., 1982; Jensen et al., 1983). As such, they have proven valuable in the study of benzodiazepine receptor multiplicity and function.

Inosine and hypoxanthine are relatively weak inhibitors of benzodiazepine binding (Huang et al., 1980; Skerritt et al., 1982b), although it is possible that brain levels sufficiently high to interact with benzodiazepine receptors could be achieved in vivo under certain physiological conditions. Further, these purines do have benzodiazepine-like activity in some behavioural assays (Skolnick et al., 1979), and like clonazepam bind selectively to central rather than peripheral benzodiazepine receptors (Skerritt et al., 1982a).

In the previous paper (Skerritt and Macdonald, 1983) we demonstrated that certain benzodiazepines and nonbenzodiazepine anticonvulsant/ anxiolytics enhanced GABA responses in mouse spinal cord ( $\mathrm{SC}$ ) neurons in cell culture at concentrations likely to be found in cerebrospinal fluid during therapy. Further, such enhancement was antagonized by Ro 15-1788, a benzodiazepine antagonist. In the present study we have investigated the effects of $\beta$-carboline and purine ligands for benzodiazepine receptors and have demonstrated a correlation between the in vivo actions of these substances and their effects upon GABA responses of mouse $\mathrm{SC}$ neurons in cell culture.

\section{Materials and methods}

Methods used in the present study are outlined in the accompanying paper (Skerritt and Mac- donald, 1984). The $\beta$-carboline esters used were a generous gift of Dr. C. Braestrup, A/S Ferrosan, Denmark. They were dissolved in vehicle $(0.1 \%$ or less dimethylsulfoxide) and applied to neurons in the same manner as the benzodiazepines. Purines were dissolved directly in recording medium. 1-Methylisoguanosine was a gift of Roche Products, Australia, and inosine, hypoxanthine and 6,6-dimethylaminopurine were purchased from Sigma.

\section{Results}

The convulsant DMCM at $100 \mathrm{nM}$ reduced GABA responses in all SC neurons tested (fig. 1A, table 1). While diazepam reversibly enhanced responses of SC neurons to iontophoretically applied GABA in a concentration-dependent fashion (see previous paper), neither $\beta$-carboline-3-carboxylic acid methyl ester ( $\beta C C M e$ ) (fig. $1 B$ ) nor $\beta C C E t$ (fig. 1C) altered GABA responses at 100 $\mathrm{nM}$ or $10 \mu \mathrm{M}$ (table 1). The corresponding propyl ester $(\beta C C P r)$ weakly but significantly enhanced GABA responses at $100 \mathrm{nM}$ (table 1 ). $\beta C C P r$ enhanced GABA responses in a concentration-dependent fashion (fig. 2, table 1); $10 \mathrm{nM}$ was ineffective while enhancement at $10 \mu \mathrm{M}(84 \pm 17 \%$, $\mathrm{n}=10$ cells) (fig. $1 \mathrm{D}$ ) was not statistically significantly different from maximal enhancement by diazepam $(81 \pm 10 \%$ at $10 \mathrm{nM}, \mathrm{n}=13$ cells $)$. $\beta C C M e(100 \mathrm{nM})$ markedly decreased diazepam enhancement of GABA responses on all 6 cells tested (fig. $3 \mathrm{~A}$, table 1$)$ while $\beta$ CCEt $(100 \mathrm{nM})$

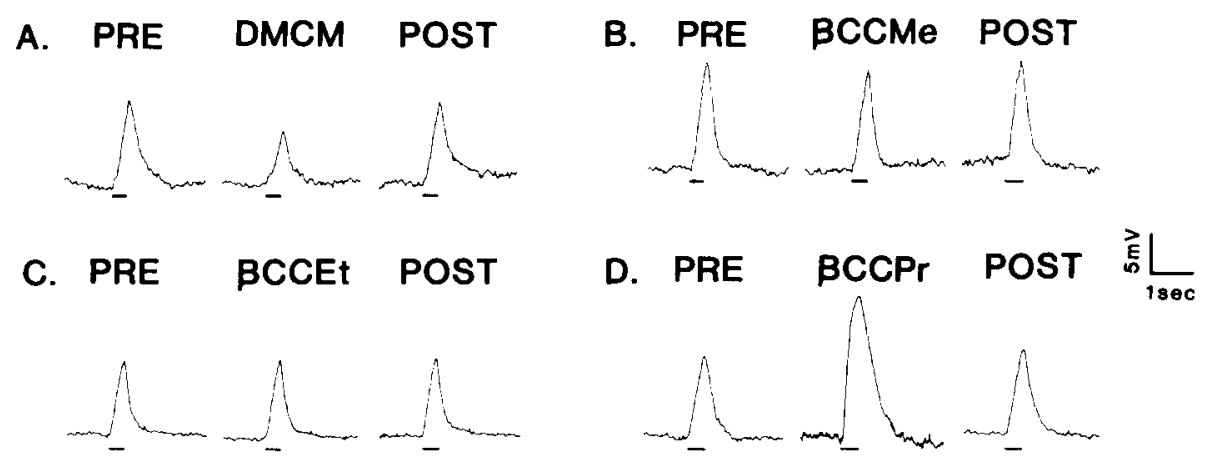

Fig. 1. Reversible modulation of GABA responses by $\beta$-carboline esters: (A) DMCM $100 \mathrm{nM}(\mathrm{MP}=-75 \mathrm{mV})$. (B) $\beta C \mathrm{CMe} 100 \mathrm{nM}$ $(\mathrm{MP}=-72 \mathrm{mV})$. (C) $\beta C C E t 100 \mathrm{nM}(\mathrm{MP}=-78 \mathrm{mV})$ (D) $\beta C C P r 10 \mu \mathrm{M}(\mathrm{MP}=-82 \mathrm{mV})$. A-D represent separate cells. 
TABLE 1

Effects of $\beta$-carboline esters upon GABA responses of cultured spinal cord neurons and their enhancement by diazepam (100 nM).

\begin{tabular}{|c|c|c|c|c|c|}
\hline & (n) & $\begin{array}{l}\text { \% Control GABA } \\
\text { response }\end{array}$ & (n) & $\begin{array}{l}\text { Inhibition of } \\
\text { diazepam }(100 \mathrm{nM}) \\
\text { enhancement of } \\
\text { GABA response }\end{array}$ & $\begin{array}{l}\% \text { cells with } \\
>20 \% \text { inhibition } \\
\text { of } \mathrm{DZ} \text { enhancement } \\
\text { of } \mathrm{GABA} \text { response }\end{array}$ \\
\hline$\overline{\text { DMCM } 100 \mathrm{nM}}$ & 9 & $53.3 \pm 5.4^{\mathrm{a}}$ & & n.t. & n.t. \\
\hline$\beta \mathrm{CCMe} 100 \mathrm{nM}$ & 6 & $98.0 \pm 3.9$ & 6 & $76.5 \pm 2.6^{b}$ & $100 \%$ \\
\hline $10 \mu \mathrm{M}$ & 6 & $106.7 \pm 3.4$ & & n.t. & n.t. \\
\hline$\beta C C E t 100 \mathrm{nM}$ & 13 & $95.2 \pm 2.9$ & 9 & $24.0 \pm 9.7$ & $44 \%$ \\
\hline $10 \mu \mathrm{M}$ & 8 & $101.9 \pm 3.9$ & & n.t. & n.t. \\
\hline$\beta C C P r 100 \mathrm{nM}$ & 18 & $114.5 \pm 2.9^{a}$ & 14 & $86.5 \pm 6.5^{b}$ & $85 \%$ \\
\hline $10 \mu \mathrm{M}$ & 10 & $183.7 \pm 17.3^{a}$ & & n.t. & n.t. \\
\hline
\end{tabular}

a $\mathrm{P}<0.001$ from control (responses to buffer containing vehicle only), Student's 2-tailed t-test. ${ }^{b} \mathrm{P}<0.001$ from mean enhancement by diazepam. $(\mathrm{n})=$ number of cells studied. $\mathrm{n} . \mathrm{t} .=$ not tested.

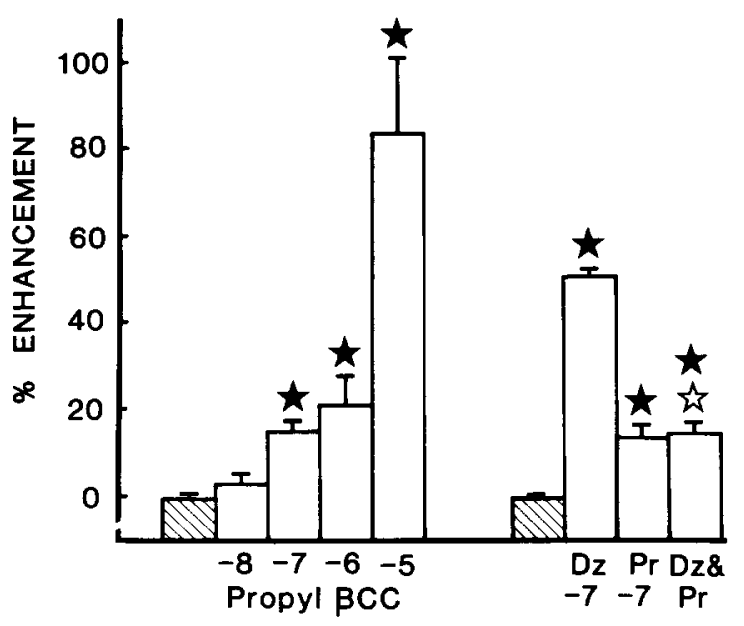

antagonized diazepam (by more than 20\%) in 4 of 9 cells studied (table 1$). \beta C C P r(100 \mathrm{nM})$ reduced further enhancement of responses by diazepam (fig. 3B, table 1).

The purine, 1-methylisoguanosine (MeIG), enhanced GABA responses weakly (fig, 4A) but in a

\section{A. CTL DZ CTL BCCMe BCCMe CTL \& $D Z$}

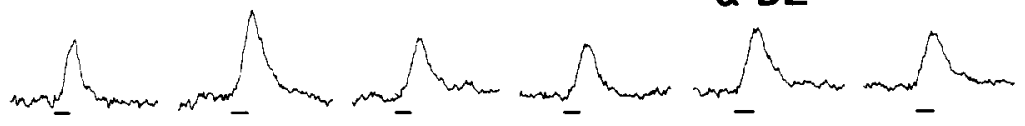

B. $\mathrm{CTL}$
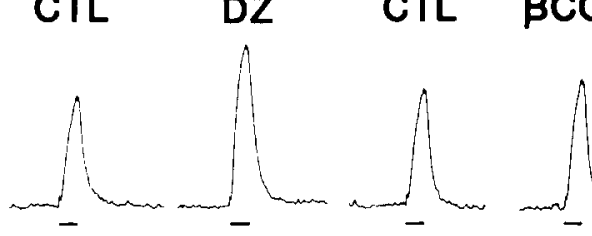

Fig. 3. Blockade of diazepam enhancement of GABA responses by $\beta$-carboline esters. (A) Diazepam (100 nM) reversibly enhanced GABA responses, and $\beta C C M e(100 \mathrm{nM})$, which itself did not alter GABA responses, blocked enhancement by diazepam. (B) Enhancement of GABA responses by $100 \mathrm{nM}$ diazepam was blocked by $\beta C C \operatorname{Pr}(100 \mathrm{nM})$ which itself produced a weak enhancement of GABA responses in SC neurons. GABA responses returned to control values within 6 min following removal of the $\beta$-carboline esters. Cell $\mathrm{A}, \mathrm{MP}=-72 \mathrm{mV}$; cell $\mathbf{B}, \mathbf{M P}=-75 \mathrm{mV}$. 
concentration-dependent fashion (table 2). Significant enhancement (8.6\%) was produced at $10 \mu \mathrm{M}$ MeIG, with $22 \%$ enhancement being produced at $500 \mu \mathrm{M}$. The purine, 6-dimethylaminopurine (DMAP), at $500 \mu \mathrm{M}$ also enhanced GABA responses (by more than $10 \%$ ) on 4 of 6 cells studied (fig. 4B, table 2). Neither inosine nor hypoxanthine enhanced GABA responses at $100 \mu \mathrm{M}$ or $1 \mathrm{mM}$; at $1 \mathrm{mM}$ GABA responses were weakly inhibited (table 2). At $100 \mu \mathrm{M}$, MeIG enhanced GABA responses and significantly reduced the further enhancement of GABA responses by diazepam (fig. $4 \mathrm{C}$, table 2). Further, inosine ( $1 \mathrm{mM}$ ) failed to alter enhancement of GABA responses by diazepam ( $100 \mathrm{nM}$ ) (fig. 4D, table 2).

In no cells studied did any of the $\beta$-carbolines or purines alter resting membrane potential or conductance. Furthermore, at a concentration which enhanced GABA responses $(10 \mu \mathrm{M})$, $\beta C C P r$, like diazepam, failed to affect glutamate responses of $\mathrm{SC}$ neurons (responses $97.4 \pm 2.4 \%$ control, $n=4$ cells).

\section{Discussion}

The results obtained on modulation of GABA responses by $\beta$-carboline esters are in keeping with their in vivo actions and their effects on GABAbenzodiazepine receptor complexes as studied by neurochemical methods. DMCM had potent convulsive activity in mice (Braestrup et al., 1982) and in the present study was found to potently antagonize GABA responses. $\beta C C M e$ had weak convulsant activity and was anxiogenic in conflict tests in mice, while $\beta C C E t$ was also anxiogenic and facilitated the convulsant activity of certain compounds, while not itself producing seizures (Braestrup et al., 1982; Oakley and Jones, 1982; Corda et al., 1983; De Carvalho et al., 1983). Neither $\beta C C M e$ nor $\beta C C E t$ reduced GABA responses in cultured SC neurons, although in cat spinal cord in situ some antagonism has been observed (Polc et al., 1981, 1982). $\beta$ CCMe reduced diazepam enhancement of GABA responses while $\beta C C E t$ had a lesser (29\% reduction) effect, which
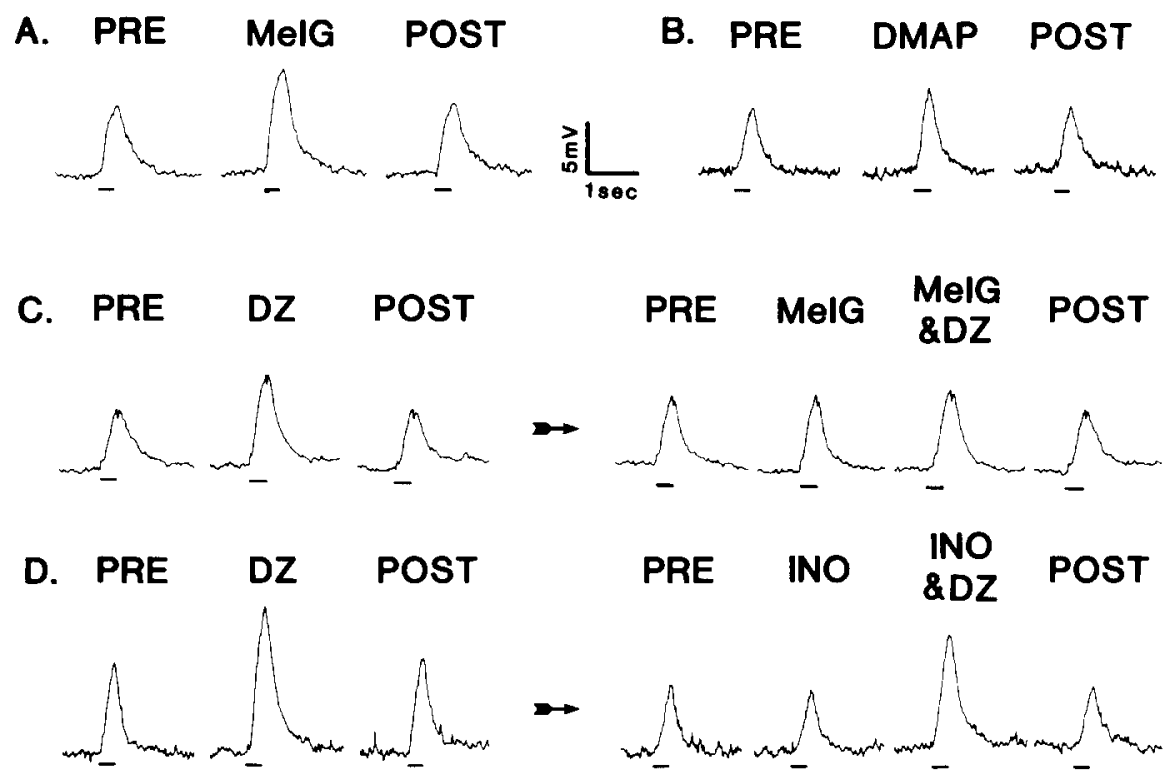

Fig. 4. Effects of certain purines upon GABA responses and their enhancement by diazepam (DZ). (A) l-Methylisoguanosine (MeIG, $500 \mu \mathrm{M} ; \mathrm{MP}=-80 \mathrm{mV}$ ) and (B) 6-dimethylaminopurine (DMAP, $500 \mu \mathrm{M} ; \mathrm{MP}=-62 \mathrm{mV}$ ) reversibly enhanced GABA responses. (C) Diazepam $(100 \mathrm{nM})$ enhancement was reduced by $100 \mu \mathrm{M}$ MelG, which itself weakly enhanced GABA responses $(\mathrm{MP}=-80$ $\mathrm{mV}$ ). (D) Inosine (INO, $100 \mu \mathrm{M}$ ) weakly depressed GABA responses but did not alter their (percentage) enhancement over control levels (PRE), by $100 \mathrm{nM}$ diazepam (MP $=-75 \mathrm{mV}$ ). 
Effects of purines and diazepam upon GABA responses of cultured spinal cord neurons.

\begin{tabular}{|c|c|c|c|c|}
\hline & & $\begin{array}{l}\text { Number of } \\
\text { cells studied } \\
\text { (n) }\end{array}$ & $\begin{array}{l}\text { Mean } \% \\
\text { enhancement }\end{array}$ & $\begin{array}{l}\% \text { cells with } \\
\text { responses } \\
\text { enhanced by } \\
\text { more than } 10 \%\end{array}$ \\
\hline \multirow[t]{3}{*}{ (1) l-Methylisoguanosine } & $10 \mu \mathrm{M}$ & 10 & $+8.6 \pm 3.6^{a}$ & 40 \\
\hline & $100 \mu \mathrm{M}$ & 29 & $+12.8 \pm 2.9^{b}$ & 48 \\
\hline & $500 \mu \mathrm{M}$ & 12 & $+22.0 \pm 4.2^{b}$ & 83 \\
\hline 6-Dimethylaminopurine & $500 \mu \mathrm{M}$ & 6 & $+25.3 \pm 6.8^{h}$ & 67 \\
\hline \multirow[t]{2}{*}{ Inosine } & $100 \mu \mathrm{M}$ & 6 & $+5.2 \pm 2.5$ & 0 \\
\hline & $1 \mathrm{mM}$ & 16 & $-8.6 \pm 3.0^{a}$ & 0 \\
\hline \multirow[t]{2}{*}{ Hypoxanthine } & $100 \mu \mathrm{M}$ & 9 & $-0.8 \pm 2.5$ & 0 \\
\hline & $1 \mathrm{mM}$ & 8 & $-15.3 \pm 3.4^{a}$ & 0 \\
\hline (2) 1-Methylisoguanosine & $100 \mu \mathrm{M}$ & 18 & $+11.8 \pm 2.9^{a}$ & 50 \\
\hline Diazepam (DZ) & $100 \mathrm{nM}$ & 18 & $+66.5 \pm 5.7^{b}$ & 100 \\
\hline I-MeIG + DZ & & 18 & $+46.1 \pm 4.6^{\circ}$ & 88 \\
\hline Inosine & $1 \mathrm{mM}$ & 8 & $-11.9 \pm 4.9^{\mathrm{a}}$ & 0 \\
\hline Diazepam (DZ) & $100 \mathrm{nM}$ & 8 & $+70.1 \pm 12.7^{\mathrm{h}}$ & 0 \\
\hline Inosine + DZ & & 8 & $+68.4 \pm 9.3^{\circ}$ & 0 \\
\hline
\end{tabular}

${ }^{\mathrm{a}} \mathrm{P}<0.05,{ }^{\mathrm{h}} \mathrm{P}<0.005$ from cells miniperfused with drug-free control medium, ${ }^{\mathrm{P}} \mathrm{P}<0.05$ from diazepam (100 nM) alone (Student's t-test, 2-tailed).

failed to achieve statistical significance. Both $\beta \mathrm{CCMe}$ and $\beta \mathrm{CCEt}$ blocked the anticonvulsant activity of diazepam in mice (Oakley and Jones, 1982).

Other neurochemical and behavioural studies have revealed results corresponding to those of this study. GABA markedly inhibited the binding of $\left[{ }^{3} \mathrm{H}\right] \mathrm{DMCM}$ (Braestrup et al., 1982) while $\beta C C M e$ and $\beta C C E t$ did not alter basal low affinity GABA binding, but inhibited its enhancement by diazepam (Skerritt et al., 1983). In keeping with neurochemical results, $\beta C C P r$ and diazepam enhanced GABA responses over a similar concentration range (Skerritt et al., 1983). Physiological investigations reveal it actually is a partial agonist since low concentrations of $\beta C C P r(100 \mathrm{nM})$, which produced only moderate enhancement of GABA responses, prevented further effects of diazepam (fig. 3). $\beta C C P r$ inhibited $\beta C C M e$ seizures (Valin et al., 1982) and antagonized audiogenic seizures in mice (Jensen et al., 1983). The latter study found that proportionately greater occupancy of benzodiazepine receptors by $\beta \mathrm{CCPr}$ than diazepam was needed for its anticonvulsant activity. This could arise from the similar potency but lower efficacy of $\beta C C P r$ relative to diazepam as an enhancer of GABA actions.
The purines, inosine and hypoxanthine, were the first described putative endogenous benzodiazepine receptor ligands. Inosine has been demonstrated to have benzodiazepine-like activity against pentylenetetrazole seizures, yet in certain behavioural models it was able to antagonize diazepam (Skolnick et al., 1979; Crawley et al., 1981). However, at no concentration tested did inosine or hypoxanthine markedly alter GABA responses, and $1 \mathrm{mM}$ inosine failed to alter response enhancement by diazepam. Inosine was a weak inhibitor of benzodiazepine binding in cultured SC neurons ( $\mathrm{K}_{\mathrm{i}} 2.8 \mathrm{mM}$, Huang et al., 1980) so it cannot be ruled out that higher inosine concentrations (e.g. $10 \mathrm{mM}$ ) may have some activity. However, the relevance of such concentrations to the in vivo actions of the purine is questionable. The finding that inosine failed to alter GABA responses is in contrast to a report of the ability of inosine to reverse diazepam inhibition of rat substantia zona reticulata neurons and to produce a diazepam-like inhibition of firing rate at higher dose (Skolnick et al., 1983). However, these effects may not necessarily be mediated by GABA-coupled benzodiazepine receptors. Inosine has also been reported to have direct effects upon membrane potential and conductance of cultured spi- 
nal neurons (MacDonald et al., 1980), although in the present experiments no direct effects of inosine or any other purine were observed.

Neurochemical studies have indicated that while the affinities of inosine and hypoxanthine for benzodiazepine antagonist binding were unaltered by $10 \mu \mathrm{M}$ GABA, the potencies of certain purines with higher receptor affinities (eg. MeIG. DMAP) could be altered by GABA, albeit in a different manner from that of diazepam (Skerritt et al., 1982b). Micromolar concentrations of these purines produced a moderate but statistically significant concentration-dependent enhancement of GABA responses in cultured SC neurons, while $100 \mu \mathrm{M}$ MelG partially blocked enhancement of GABA responses by diazepam. Certain purines may therefore act as partial agonists at benzodiazepine receptors. Taken together with the apparent selectivity of purines for central rather than peripheral benzodiazepine receptors (Skerritt et al., 1982a), it is possible that purines could be developed with clinically useful selective actions on benzodiazepine receptors.

\section{Acknowledgements}

We thank Hoffmann-La Roche Nutley, NJ and Sydney, Australia and A/S Ferrosan. Denmark for providing experimental compounds. JHS is the recipient of an award from the Rotary Foundation of Rotary International. The research was funded by NIH grants NS 00408 and NS 19692 to RLM.

\section{References}

Asano, T., and S. Spector, 1979, Identification of inosine and hypoxanthine as endogenous ligands for the brain benzodiazepine receptor sites, Proc. Nat. Acad. Sci. U.S.A. 76, 1977.

Braestrup, C. and M. Nielsen, 1980, Searching for endogenous benzodiazepine receptor ligands, Trends Pharmacol. Sci. 1. 424.

Braestrup, C., M. Nielsen and C.E. Olsen, 1980, Urinary and brain $\beta$-carboline-3-carboxylates as potent inhibitors of brain benzodiazepine receptors, Proc. Nat. Acad. Sci. U.S.A. $77,2288$.

Braestrup, C., P. Schmiechen, G. Neef, M. Nielsen and E.N. Petersen, 1982, Interaction of convulsive ligands with benzodiazepine receptors, Science 216, 1241.

Braestrup, C., and R.F. Squires, 1977, Specific benzodiazepine receptors in rat brain characterized by high affinity $\left[{ }^{3} \mathrm{H}\right]$-di- azepam binding, Proc. Nat. Acad. Sci. U.S.A. 74, 3805.

Copeda, C., T. Tanaka. R. Besselievre, P. Potier, R. Naguet and J. Rossier, 1981. Proconvulsant effects in baboons of $\beta$ carboline, a putative endogenous ligand for henzodiazepine receptors. Neurosci. Lett. 24, 53.

Chiu, T.H. and H.C. Rosenberg, 1981, Endogenous modulator of benzodiazepine binding in rat cortex. J. Neurochem. 36 , 336.

Corda, M.G., W.D. Blaker, W.B. Mendelson. A. Guidotti and E. Costa, 1983, $\beta$-Carbolines enhance shock-induced suppression of drinking in rats, Proc. Nat. Acad. Sci. U.S.A. $80,2072$.

Crawley, J.N.. P.J. Marangos, S.M. Paul, P. Skolnick and F.K. Goodwin, 1981. Interaction between purine and benzodiazepine: inosine reverses diazepam-induced stimulation of mouse exploratory behavior, Science 211, 725

Da Carvalho, L.P.. G. Greksch, G. Chapouthier and J. Rossier. 1983. Anxiogenic and non-anxiogenic benzodiazepinte antagonists. Nature 301, 64 .

Guidotti. A.. C.M. Forchetti. M.G. Corda, D. Konkel, C.D. Bennett and E. Costa. 1983. Isolation, characterization and purification to homogeneity of an endogenous polypeptide with agonistic action on benzodiazepine receptors. Proc. Nat. Acad. Sci. U.S.A. 80. 3531.

Huang. A., J.L. Barker, S.M. Paul, V. Moncada and P. Skolnick, 1980, Characterization of benzodiazepine receptors in primary cultures of fetal mouse brain and spinal cord neurons. Brain Res. 190. 485.

Jensen, L.H., E.N. Petersen and C. Braestrup. 1983. Audiogenic seizures in DBA/2 and inverse agonists, Life Sci. 33, 393.

MacDonald, J.F., J.L. Barker, S.M. Paul. P.G. Marangos and P. Skolnick, 1980, Inosine may be an endogenous ligand for benzodiazepine receptors on cultured spinal neurons, Science 205, 715 .

Möhler, H., 1981, Benzodiazepine receptors: Are there endogenous ligands in the brain?, Trends Pharmacol. Sci. 2, 116.

Möhler. H. and T. Okada, 1977. Benzodiazepine receptor: demonstration in the central nervous system. Science 198. 849.

Möhler, H., P. Polc, R. Cumin, L. Pieri and R. Kettler, 1979. Nicotinamide is a brain constituent with benzodiazepine-like actions, Nature 278, 563.

Oakley, N.R. and B.J. Jones, 1982, Differential pharmacological effects of $\beta$-carboline-3-carboxylate esters, Neuropharmacology 21, 587 .

Polc, P., E.P. Bonetti, R. Schaffner and W. Haefeley, 1982. A three-state model of the benzodiazepine receptor explains the interactions between the benzodiazepine antagonist Ro 15-1788, benzodiazepine tranquilizers and phenobarbitone, Naunyn-Schmiedeb. arch. Pharmacol. 321, 260.

Polc, P.N.. N. Robert and D.M. Wright, 1981, Ethyl- $\beta$-carboline-3-carboxylate antagonizes the action of GABA and benzodiazepines in the hippocampus. Brain Res. 217, 216.

Skerritt, J.H., S. Chen Chow, G.A.R. Johnston and L.P. Davies, 1982a, Purines interact with 'central' but not 'peripheral' benzodiazepine binding sites, Neurosci. Lett. 34, 63 . 
Skerritt, J.H., L.P. Davies, S. Chen Chow and G.A.R. Johnston, 1982b, Contrasting regulation by GABA of the displacement of benzodiazepine antagonist binding by benzodiazepine agonists and purines, Neurosci. Lett. 32, 169.

Skerritt, J.H., G.A.R. Johnston and C. Braestrup, 1983, Modulation of GABA binding to rat brain membranes by alkyl $\beta$-carboline-3-carboxylate esters, European J. Pharmacol. $86,299$.

Skerritt, J.H. and R.L. Macdonald, 1984, Benzodiazepine (BZ) receptor ligand actions on GABA responses: I. BZ's, CL 218872 and zopiclone, European J. Pharmacol. 101, 127.

Skolnick, P., D. Hommer and S.M. Paul, 1983, Benzodiazepine antagonists, in: Pharmacology of Benzodiazepines, eds. E. Usdin, P. Skolnick, J.F. Tallman, D. Greenblatt and S.M. Paul (Macmillan, New York) p. 441.
Skolnick, P., P.J. Marangos, F.K. Goodwin, M. Edwards and S. Paul, 1978, Identification of inosine and hypoxanthine as endogenous inhibitors of $\left[{ }^{3} \mathrm{H}\right]$-diazepam binding in the central nervous system, Life Sci. 23, 1973.

Skolnick, P., P.J. Syapin, B.A. Paugh, V. Moncada, P.J. Marangos and S.M. Paul, 1979, Inosine, an endogenous ligand of the brain benzodiazepine receptor, antagonizes pentylenetetrazole-evoked seizures, Proc. Nat. Acad. Sci. U.S.A. $76,1515$.

Valin, A., R.H. Dodd, D.R. Liston, P. Potier and J. Rossier, 1982, Methyl- $\beta$-carboline-induced convulsions are antagonized by Ro15-1788 and by propyl- $\beta$-carboline, European $\mathrm{J}$. Pharmacol. 85, 93, 